\title{
SURVIVAL OF PATIENTS WITH RECTAL CANCER
}

\author{
Bohdan Tataryn, Anna Kryzhanivska, Iryna Dyakiv, Alina Andriiv \\ IVANO-FRANKIVSK NATIONAL MEDICAL UNIVERSITY, IVANO-FRANKIVSK, UKRAINE
}

\begin{abstract}
The aim: To evaluate the early and late results of treatment of rectal cancer patients after special treatment methods with a view to indentifying optimal method of treatment in correlation with the stage of the disease.

Materials and methods: The study is based on the results of observation of 779 patients with stage II, III and IV rectal cancer (RC) who were divided into groups according to the treatment (surgery, surgery + chemotherapy, chemotherapy, surgery + chemotherapy + radiation therapy, radiation therapy + surgery, radiation therapy).

Results: According to the results obtained, the overall survival of patients correlates with the stage of rectal cancer: we see the highest percentage of patients'survival in stage II and, accordingly, the lowest - in stage IV in each of the studied time intervals.

Conclusions: The use of combined and integrated treatment in patients with stages II and stage III and the use of chemotherapy in stage IV RC gives a higher rate of cumulative survival of patients at each of the studied intervals
\end{abstract}

KEY WORDS: rectal cancer, surgical treatment of rectal cancer, chemotherapy of rectal cancer

Wiad Lek. 2021;74(9 p.l):2044-2051

\section{INTRODUCTION}

Rectal cancer is one of the most common malignancies: about 100,000 and 40,000 new cases are reported annually in Europe and the United States, respectively [1].

According to the data of the National Chancellery of Ukraine, the structure of malignant neoplasms $(\mathrm{MN})$ among population of Ukraine (excluding non-melanoma skin cancer) RC $5.4 \%$ occur in women and $6.8 \%$ - in, men. The morbidity among women with RC aged $55-74$ is $6.1 \%$, and among men $7.2 \%$, and among women over 75 years old $-7.3 \%$

The mortality of the population of Ukraine with malignant neoplasms in men aged $55-74$ is $6,2 \%$, in men aged 75 and older $-9,1 \%$. Among women aged 75 and older the mortality is $8,4 \%$ (2018 - refined information).

In 2019 according to the National Chancellery of Ukraine $23,7 \%$ and $19,7 \%$ of primary identified patients with RC stage III and stage IV were dianosed. 2019 special treatment was introduced to $72,1 \%$ of patients. Mortality within a year was $25,4 \%[2]$.

Treatment for patients with advanced rectal cancer includes surgery, radiation and chemotherapy $[3,4]$.

The nature and extent of surgery depends on the location and spread of the tumour, complications and the general condition of the patient [5-7].

There is no definitive treatment and diagnosis standard for locally advanced rectal cancer, and sphincter-sparing surgery is not always possible. [8].

According to the NCCN Clinical Practice Guidelines in Oncology: there is no clear answer regarding the use of chemotherapy for the treatment of patients with stage II rectal cancer, as well as elderly patients [9-12].
Patient survival is an objective indicator of the effectiveness of the therapy used.

Survival of RC patients correlates with the stage of the disease. There are many prognostic factors that affect the survival of patients: the presence of tumour cells at the edge of resection, lymphatic vascular invasion, microsatellite instability, pereneural invasion, and so on $[13,14]$.

From the standpoint of the above, it is important to conduct further research aimed at developing new options for the treatment of patients with rectal cancer.

\section{THE AIM}

The purpose of the study is to evaluate the immediate and long-term results of treatment of patients with rectal cancer after special treatment in the CHPI «Precarpathian Clinical Oncology Center» in order to determine the effective treatment method of the stage of the disease.

\section{MATERIALS AND METHODS}

The basis of the study deals with the results of observation of 779 patients with rectal cancer in Communal Health Protection Institution «Precarpathian Clinical Oncology Center» from 2012 to 2018.

The direct and long-term results of treatment of rectal cancer were studied and evaluated.

All patients were divided according to the stage of the disease (TNM system): patients with stage II, stage III and stage IV rectal cancer. We analyzed the results obtained by comparing the investigated parameters within each of the 


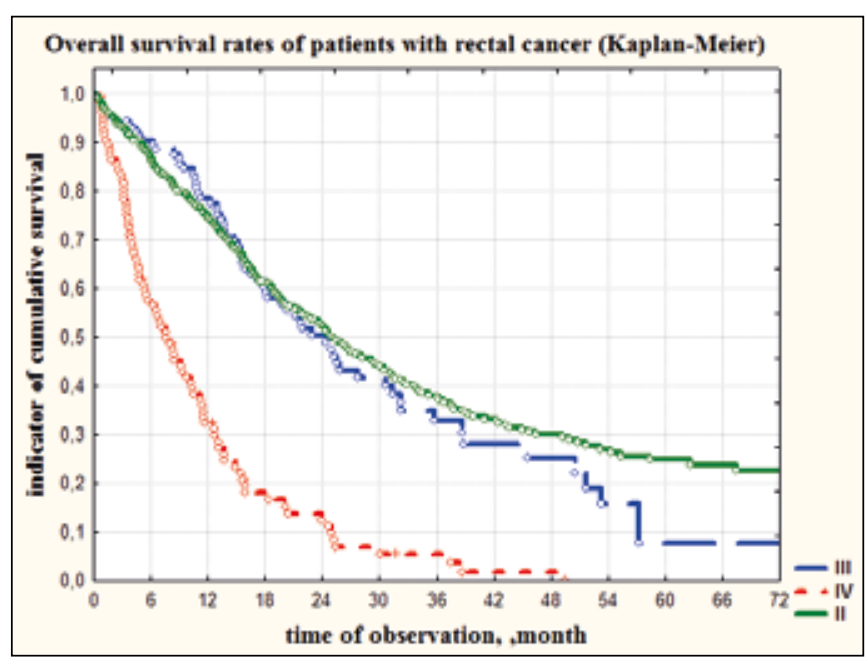

Fig. 1. Overall survival rates of patients with $R C$, taking into account the stage of the disease

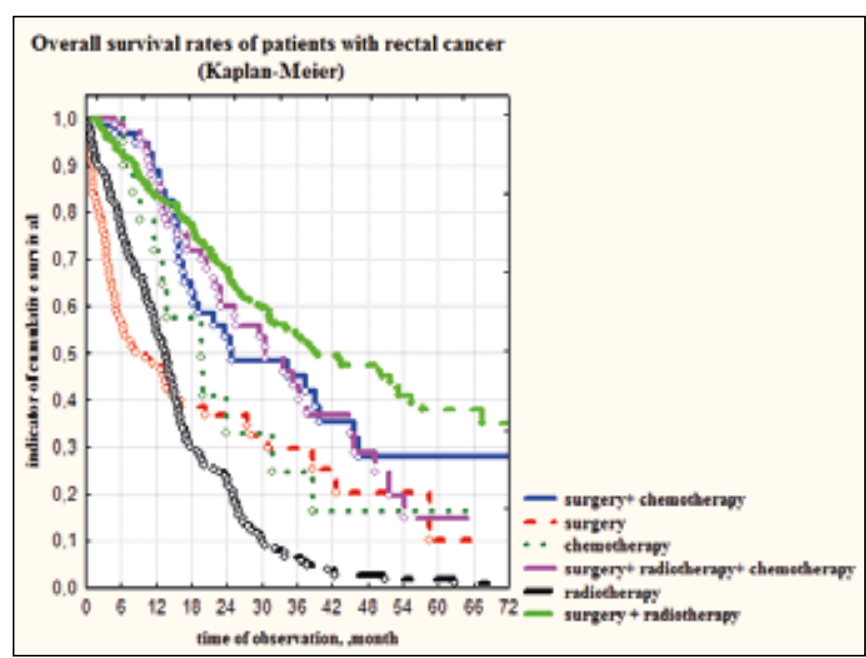

Fig. 2. Overall survival of patients with stage I-IV RC according to the treatment method

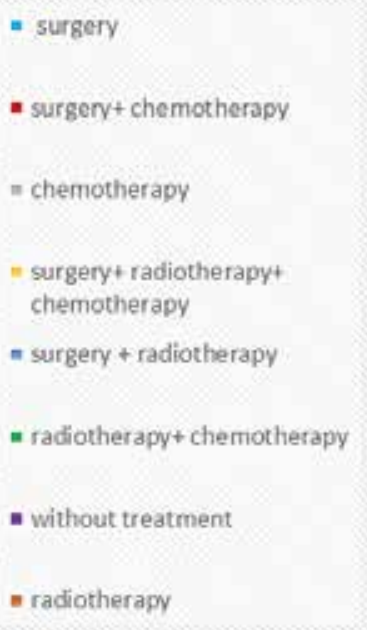

Fig. 3. Structure of treatment of stage II RC

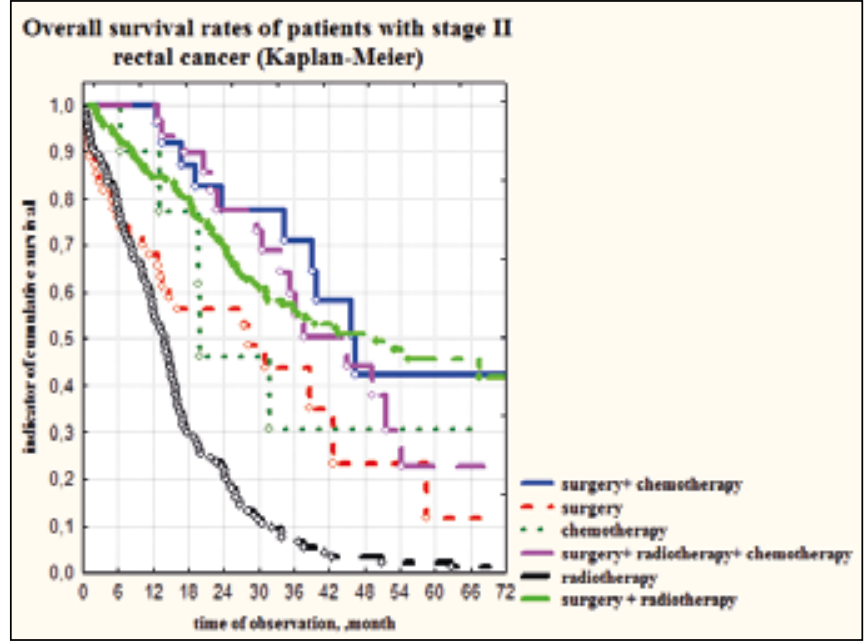

Fig. 4. Overall survival rates of patients with stage II RC, according to the treatment method

stages of rectal cancer and together for the total number of patients, determining their effect on their survival.

\section{RESULTS}

For the initial analysis of the effect of treating patients on the overall survival rates, we calculated the cumulative survival rates and the percentage of the overall survival of rectal cancer in patients, taking into account the stage of the disease, but without treatment received (Fig. 1)

Analyzing the results we see the highest percentage of survival in stage II and, accordingly, the lowest - in stage IV in each of the studied time intervals, starting with the 24th month of observation (Table I).

At the next stage of the study we analyzed what treatment methods were received by the patients. The treatment methods included the following: surgery, surgery + chemotherapy, chemotherapy, surgery + chemotherapy + radiation therapy, radiotherapy + surgery, radiotherapy (Table II).

The cumulative survival rate is determined for the total number of patients depending on the treatment method (Fig. 2).

According to the calculations $\mathrm{p}=0.00000$, which indicates the effect of the treatment method on the cumulative survival rate of patients for the total number of patients.

For the total number of patients under study, regardless of the rectal cancer stage, at each time intervals, we ob- 


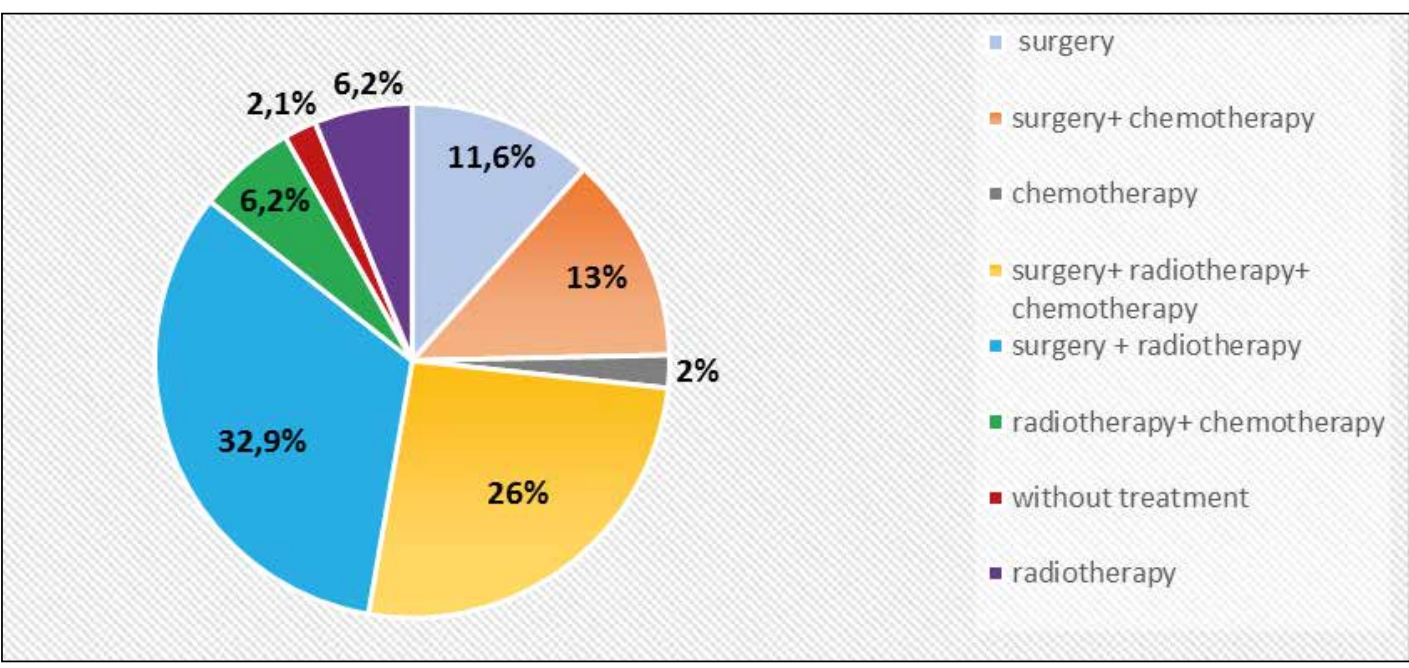

Fig. 5. Structure of treatment of stage III RC

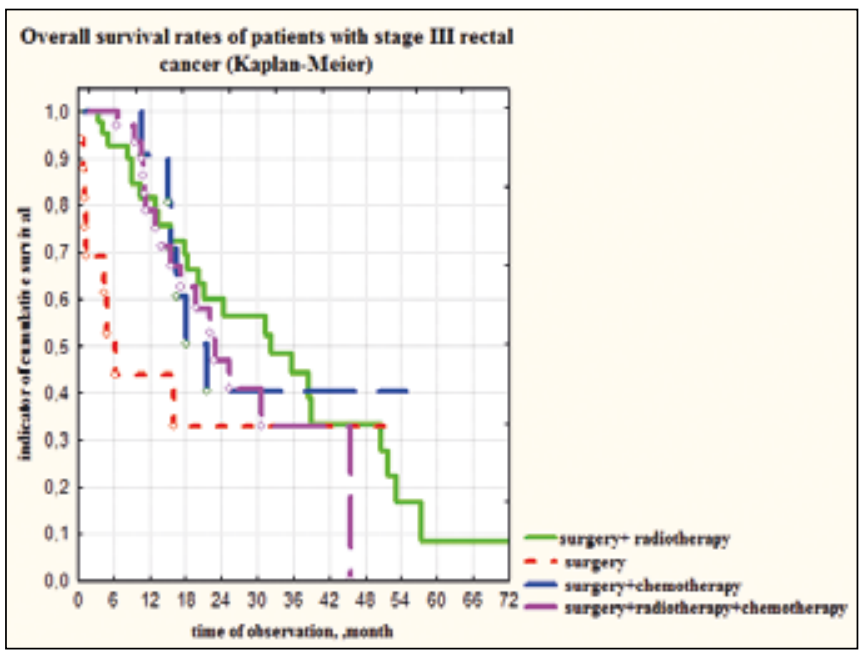

Fig. 6. Overall survival rates of patients with stage III RC, according to the treatment method

served a higher percentage of patients who survived with the combined and integrated treatment than patients, who received only surgery, radiotherapy or chemotherapy (Table III, Table IV).
In order to determine the best treatment method for patients with rectal cancer, we analyzed the overall survival rates separately for stage II, stage III and stage IV of the disease, taking into account methods of treatment of patients.

\section{ANALYSIS OF THE CUMULATIVE SURVIVAL RATE OF PATIENTS WITH STAGE II RECTAL CANCER}

There was $67.8 \%$ of the total number of patients ( 528 people) with stage II rectal cancer, $97.2 \%$ of patients received special treatment (513 patients). Surgical treatment was received by 67 patients $(12.7 \%)$, surgery + chemotherapy - by 32 people $(6.1 \%)$, chemotherapy - by 15 patients $(2.8 \%)$, radiation therapy - by 144 patients (27.3\%), surgery + chemotherapy + radiotherapy- $(6.4 \%)$, surgery + radiotherapy by $40.3 \%$ and chemotherapy + radiotherapy - by $1.5 \%$ of patients (8 people) (Fig. 3).

Analysis of the cumulative survival rate of patients depending on treatment method (Fig. 4).

According to the calculations $\mathrm{p}=0.00000$, which indicates the effect of treatment method on the cumulative survival rate of patients.

For patients with stage II rectal cancer, at each studied time intervals, starting with 24 th month of observation,

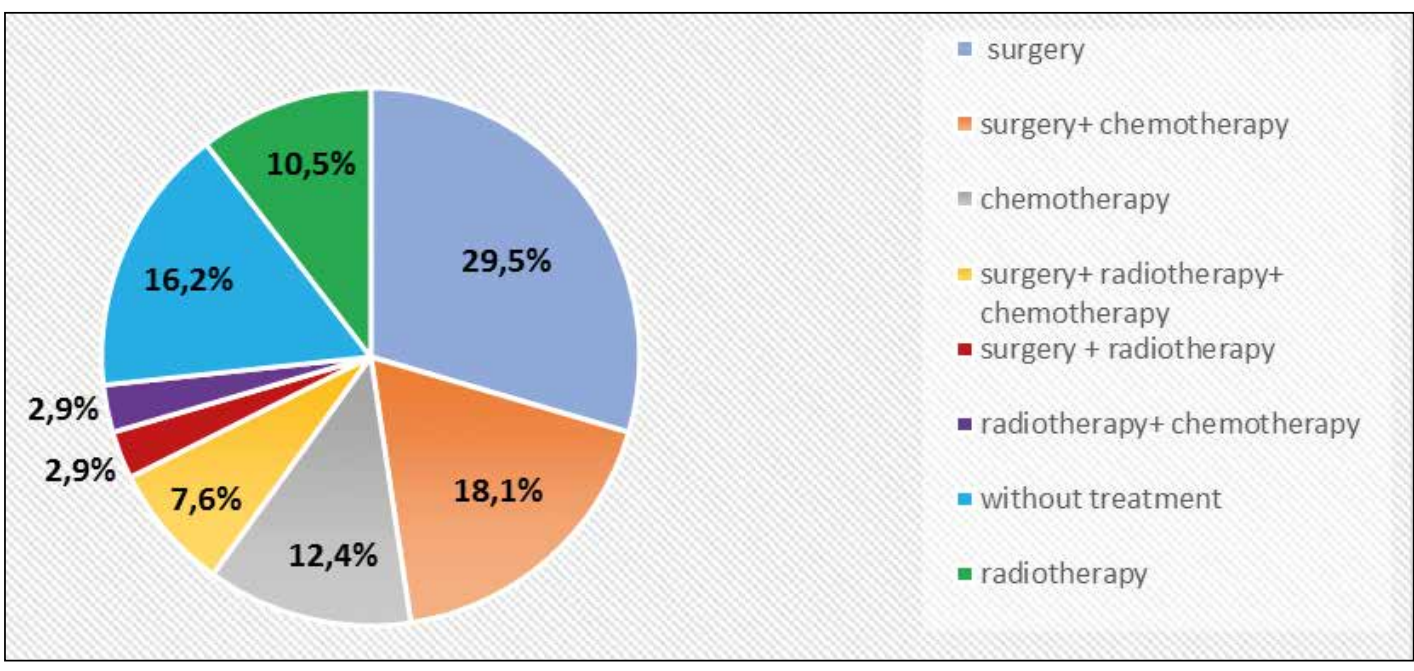

Fig. 7. Structure of treatment of stage IV RC 


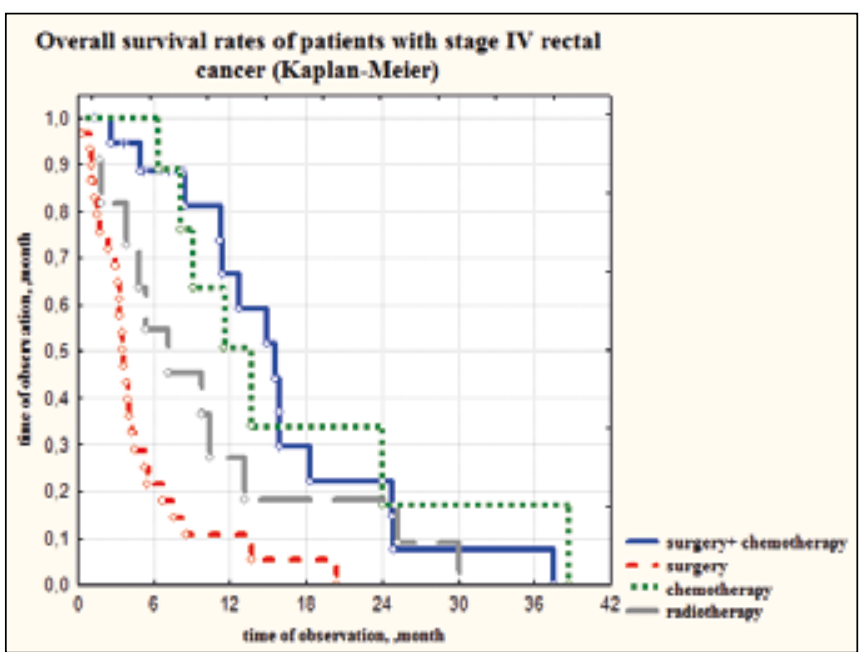

Fig. 8. Overall survival rates of patients with stage IV RC, according to the treatment method

we see a higher percentage of patients, who survived with a combined and integrated treatment than patients with surgery, radiotherapy or chemotherapy. Thus, $8.4 \%$, $1.6 \%$ and $7.7 \%$ of patients with surgery, radiotherapy or chemotherapy survived on the 5 th year of observation.. The smallest percentage of the survived patients is noted in the group with the use of radiotherapy as a treatment method only. Then, the same indicators in patients who received treatment are observed: surgery + radiation therapy, surgery + radiation therapy $+\mathrm{CT}$ and surgery + CT- $45.6 \%, 21.1 \%$ and 30.0\% respectively (Table V, Table VI).

\section{ANALYSIS OF THE CUMULATIVE SURVIVAL RATE OF PATIENTS WITH STAGE III RECTAL CANCER}

There were $18.7 \%$ of patients (146 people) with stage III rectal cancer. $97.9 \%$ of patients have undergone special treatment (143 patients). Surgery was received by 17 patients $(11.6 \%)$, surgery + chemotherapy - by 19 people (13\%), chemotherapy - by 3 patients $(2 \%)$, radiotherapy by 9 patients $(6.2 \%)$, surgery + chemotherapy + radiotherapy - by 38 patients (26\%), surgical + radiotherapy - by 48 patients $(32.9 \%)$ and chemotherapy + radiotherapy by $6.2 \%$ of patients ( 9 people) (Fig. 5).

Analysis of the cumulative survival rate of patients depending on treatment method (Fig. 6).

According to the calculations $\mathrm{p}=0.0111$, which indicates the effect of treatment method on the cumulative survival rate of patients.

For patients with stage III RC we see a higher percentage of survival in the group of parients, who received surgery + radiotherapy at each of the studied time intervals, starting from the 24th month of observation. This is the only group of patients with stage III RC, where the survival was seen on the 5 th year of observation.

The smallest percentage of patients survived is noted in the group of patients, who received surgery compared with combined and integrated therapy on the 6th, 12th, 24th and 36th months of observation.

Thus, the patients who survived on the 3rd year of observation received only surgery $-14.1 \%$, against $45.4 \%$ and $32.4 \%$ patients - with combined treatment (surgery + radiation therapy) and complex treatment (surgery + radiotherapy + chemotherapy) respectively. (Table VII).

Table I. Overall survival rates of patients with rectal cancer (\%)

\begin{tabular}{ccccccc}
\hline \multirow{2}{*}{$\begin{array}{c}\text { Time of observation, } \\
\text { month }\end{array}$} & \multicolumn{3}{c}{ \% of patients survived } & \multicolumn{3}{c}{ Standard error } \\
\cline { 2 - 7 } & Stage II & Stage III & Stage IV & Stage II & Stage III & Stage IV \\
\hline 6 & 87.2 & 90.2 & 58.0 & \pm 1.5 & \pm 2.6 & \pm 4.9 \\
\hline 12 & 74.9 & 78.9 & 33.0 & \pm 2.0 & \pm 3.8 & \pm 4.9 \\
\hline 24 & 52.6 & 50.9 & 14.4 & \pm 2.5 & \pm 5.3 & \pm 3.9 \\
\hline 36 & 38.1 & 33.8 & 5.6 & \pm 2.6 & \pm 5.7 & \pm 2.7 \\
\hline 48 & 29.9 & 26.5 & 0.9 & \pm 2.7 & \pm 1.3 & \pm 5.9 \\
\hline 60 & 24.7 & 11.0 & & \pm 2.8 & & \pm \\
\hline
\end{tabular}

Table II. General characteristics of the received treatment in patients

\begin{tabular}{|c|c|c|c|c|}
\hline Treatment & Stage II & Stage III & Stage IV & Total \\
\hline Surgery & 67 & 17 & 31 & 115 \\
\hline Chemotherapy & 15 & 3 & 13 & 31 \\
\hline Surgery+ Chemotherapy & 32 & 19 & 19 & 70 \\
\hline Surgery+ Chemotherapy + Radiotherapy & 34 & 38 & 8 & 80 \\
\hline Surgery+ Radiotherapy & 213 & 48 & 3 & 264 \\
\hline Radiotherapy & 144 & 9 & 11 & 164 \\
\hline Chemotherapy + Radiotherapy & 8 & 9 & 3 & 20 \\
\hline Total & 513 & 143 & 88 & 744 \\
\hline
\end{tabular}


Table III. Overall survival (\%) of patients with rectal cancer, depending on method of treatment

\begin{tabular}{|c|c|c|c|c|c|c|}
\hline \multirow{2}{*}{$\begin{array}{l}\text { Time of } \\
\text { observation, } \\
\text { month }\end{array}$} & \multicolumn{6}{|c|}{$\%$ of patients survived } \\
\hline & Surgery & Radiotherapy & Chemotherapy & $\begin{array}{c}\text { Surgery+ } \\
\text { Chemotherapy }\end{array}$ & $\begin{array}{c}\text { Surgery + } \\
\text { Radiotherapy + } \\
\text { Chemotherapy }\end{array}$ & $\begin{array}{c}\text { Surgery + } \\
\text { Chemotherapy }\end{array}$ \\
\hline 6 & 59.0 & 78.5 & 98.0 & 93.1 & 98.7 & 96.8 \\
\hline 12 & 49.5 & 56.7 & 71.5 & 83.7 & 87.2 & 89.0 \\
\hline 24 & 37.9 & 23.9 & 40.9 & 68.2 & 60.4 & 54.0 \\
\hline 36 & 30.7 & 6.4 & 24.5 & 54.5 & 43.9 & 45.7 \\
\hline 48 & 20.2 & 2.8 & 12.3 & 47.6 & $29, .5$ & 28.0 \\
\hline 60 & 8.1 & 1.4 & 6.9 & 38.3 & 14.6 & 22.5 \\
\hline
\end{tabular}

Table IV. Calculation of standard error

\begin{tabular}{|c|c|c|c|c|c|c|}
\hline \multirow{2}{*}{$\begin{array}{l}\text { Time of } \\
\text { observation, } \\
\text { month }\end{array}$} & \multicolumn{6}{|c|}{ Standard error } \\
\hline & Surgery & Radiotherapy & Chemotherapy & $\begin{array}{c}\text { Surgery + } \\
\text { Radiotherapy }\end{array}$ & $\begin{array}{c}\text { Surgery + } \\
\text { Radiotherapy + } \\
\text { Chemotherapy }\end{array}$ & $\begin{array}{c}\text { Surgery+ } \\
\text { Chemotherapy }\end{array}$ \\
\hline 6 & \pm 4.8 & \pm 3.3 & \pm 2.7 & \pm 1.6 & \pm 1.3 & \pm 2.2 \\
\hline 12 & \pm 5.1 & \pm 4.1 & \pm 10.3 & \pm 2.5 & \pm 4.0 & \pm 4.2 \\
\hline 24 & \pm 5.3 & \pm 3.7 & \pm 13.1 & \pm 3.3 & \pm 6.4 & \pm 7.3 \\
\hline 36 & \pm 5.8 & \pm 2.2 & \pm 11.9 & \pm 3.8 & \pm 7.1 & \pm 7.6 \\
\hline 48 & \pm 7.2 & \pm 1.5 & \pm 9.3 & \pm 4.1 & \pm 7.7 & \pm 7.8 \\
\hline 60 & \pm 6.9 & \pm 1.1 & \pm 6.6 & \pm 4.6 & \pm 7.3 & \pm 8.0 \\
\hline
\end{tabular}

Table V. Overall survival (\%) of patients with stage II rectal cancer depending on method of treatment

\begin{tabular}{|c|c|c|c|c|c|c|}
\hline \multirow{2}{*}{$\begin{array}{c}\text { Time of } \\
\text { observation, } \\
\text { month }\end{array}$} & \multicolumn{6}{|c|}{$\%$ of patients survived } \\
\hline & Surgery & Radiotherapy & Chemotherapy & $\begin{array}{c}\text { Surgery + } \\
\text { Radiotherapy }\end{array}$ & $\begin{array}{c}\text { Surgery + } \\
\text { Radiotherapy + } \\
\text { Chemotherapy }\end{array}$ & $\begin{array}{c}\text { Surgery + } \\
\text { Chemotherapy }\end{array}$ \\
\hline 6 & 76.9 & 79.9 & 96.2 & 93.5 & 98.5 & 98.2 \\
\hline 12 & 68.8 & 57.6 & 86.0 & 84.9 & 96.8 & 96.3 \\
\hline 24 & 55.5 & 22.8 & 43.7 & 70.6 & 74.9 & 74.7 \\
\hline 36 & 43.3 & 7.4 & 24.3 & 57.2 & 58.0 & 66.2 \\
\hline 48 & 22.5 & 3.2 & 13.6 & 50.8 & 42.6 & 39.3 \\
\hline 60 & 8.4 & 1.6 & 7.7 & 45.6 & 21.1 & 30.0 \\
\hline
\end{tabular}

Table VI. Calculation of standard error

\begin{tabular}{|c|c|c|c|c|c|c|}
\hline \multirow{2}{*}{$\begin{array}{l}\text { Time of } \\
\text { observation, } \\
\text { month }\end{array}$} & \multicolumn{6}{|c|}{ Standard error } \\
\hline & Surgery & Radiotherapy & Chemotherapy & $\begin{array}{c}\text { Surgery + } \\
\text { Radiotherapy }\end{array}$ & $\begin{array}{c}\text { Surgery + } \\
\text { Radiotherapy + } \\
\text { Chemotherapy }\end{array}$ & $\begin{array}{c}\text { Surgery + } \\
\text { Chemotherapy }\end{array}$ \\
\hline 6 & \pm 5.4 & \pm 3.5 & \pm 5.3 & \pm 1.8 & \pm 2.2 & \pm 2.5 \\
\hline 12 & \pm 6.2 & \pm 4.4 & \pm 10.7 & \pm 2.6 & \pm 3.1 & \pm 3.7 \\
\hline 24 & \pm 7.1 & \pm 3.9 & \pm 18.4 & \pm 3.6 & \pm 8.3 & \pm 9.0 \\
\hline 36 & \pm 8.5 & \pm 2.5 & \pm 15.5 & \pm 4.2 & \pm 9.8 & \pm 10.3 \\
\hline 48 & \pm 11.7 & \pm 1.8 & \pm 11.8 & \pm 4.5 & \pm 1.5 & \pm 12.1 \\
\hline 60 & \pm 8.2 & \pm 1.3 & \pm 8.0 & \pm 4.9 & \pm 10.4 & \pm 12.4 \\
\hline
\end{tabular}


Table VII. Overall survival (\%) of patients with stage III rectal cancer depending on method of treatment

\begin{tabular}{|c|c|c|c|c|c|c|c|c|}
\hline \multirow{2}{*}{$\begin{array}{l}\text { Time of } \\
\text { observation, } \\
\text { month }\end{array}$} & \multicolumn{4}{|c|}{$\%$ of patients survived } & \multicolumn{4}{|c|}{ Standard error } \\
\hline & surgery & $\begin{array}{c}\text { surgery+ } \\
\text { radiotherapy }\end{array}$ & $\begin{array}{c}\text { surgery+ } \\
\text { radiotherapy+ } \\
\text { chemotherapy }\end{array}$ & $\begin{array}{c}\text { surgery+ } \\
\text { chemotherapy }\end{array}$ & surgery & $\begin{array}{c}\text { surgery+ } \\
\text { radiotherapy }\end{array}$ & $\begin{array}{c}\text { surgery+ } \\
\text { radiotherapy+ } \\
\text { chemotherapy }\end{array}$ & $\begin{array}{c}\text { surgery+ } \\
\text { chemotherapy }\end{array}$ \\
\hline 6 & 53.3 & 93.1 & 98.6 & 96.9 & \pm 12.8 & \pm 3.8 & \pm 1.9 & \pm 4.3 \\
\hline 12 & 44.4 & 82.2 & 79.5 & 88.8 & \pm 13.5 & \pm 6.2 & \pm 7.2 & \pm 8.7 \\
\hline 24 & 25.0 & 60.2 & 48.1 & 40.5 & \pm 14.6 & \pm 8.4 & \pm 10.4 & \pm 15.2 \\
\hline 36 & 14.1 & 45.4 & 32.4 & 27.8 & \pm 11.6 & \pm 9.1 & \pm 11.7 & \pm 14.9 \\
\hline 48 & 7.0 & 32.9 & & 15.6 & \pm 7.6 & \pm 9.5 & & \pm 12.3 \\
\hline 60 & & 9.9 & & & & \pm 7.1 & & \\
\hline
\end{tabular}

Table VIII. Overall survival (\%) of patients with stage IV rectal cancer depending on method of treatment

\begin{tabular}{|c|c|c|c|c|c|c|c|c|}
\hline \multirow{2}{*}{$\begin{array}{l}\text { Time of } \\
\text { observation, } \\
\text { month }\end{array}$} & \multicolumn{4}{|c|}{$\%$ of patients survived } & \multicolumn{4}{|c|}{ Standard error } \\
\hline & surgery & radio-therapy & $\begin{array}{c}\text { surgery+ } \\
\text { chemotherapy }\end{array}$ & chemotherapy & surgery & $\begin{array}{l}\text { radio- } \\
\text { therapy }\end{array}$ & $\begin{array}{c}\text { surgery+ } \\
\text { chemotherapy }\end{array}$ & chemotherapy \\
\hline 6 & 21.6 & 54.5 & 88.6 & 95.2 & \pm 7.8 & \pm 15.0 & \pm 7.6 & \pm 6.6 \\
\hline 12 & 5.4 & 27,3 & 68.1 & 50.4 & \pm 4.8 & \pm 13.4 & \pm 11.9 & \pm 16.7 \\
\hline 24 & & 13.6 & 22.7 & 27.0 & & \pm 10.3 & \pm 11.4 & \pm 16.9 \\
\hline 36 & & & 3.8 & 6.8 & & & \pm 5.2 & \pm 9.3 \\
\hline
\end{tabular}

Table IX. Investigation of the correlation between the studied parameters

\begin{tabular}{ccccc}
\hline Correlation & No of observation & Gamma & Z & p \\
\hline Stage \& treatment & 744 & 0.255089 & 6.78522 & 0.000000 \\
\hline Stage \& chemotherapy & 200 & 0.083491 & 1.21594 & 0.224006 \\
\hline Status \& treatment & 744 & 0.093067 & 2.44633 & 0.014432 \\
\hline Status \& chemotherapy & 200 & 0.073177 & 0.94004 & 0.347195 \\
\hline Sex \& treatment & 744 & 0.106212 & 2.67540 & 0.007464 \\
\hline Sex \& chemotherapy & 200 & 0.043430 & 0.55040 & 0.582047 \\
\hline Localization \& treatment & 744 & 0.675667 & 15.94777 & 0.000000 \\
\hline Localization \& chemotherapy & 200 & 0.192712 & 2.29974 & 0.021463 \\
\hline
\end{tabular}

\section{ANALYSIS OF THE CUMULATIVE SURVIVAL RATE OF PATIENTS WITH STAGE IV RECTAL CANCER (RC)} There were $13.5 \%$ of patients (105 people) with stage IV rectal cancer. 88 patients have undergone special treatment (83.8\%). Surgery was received by 31 patients $(29.5 \%)$, surgery + chemotherapy - by 19 people $(18.1 \%)$,chemotherapy - by 13 people (12.4\%) and radiation therapy by 11 patients $(10.5 \%) .8$ patients received surgery + chemotherapy + radiotherapy $(7.6 \%)$ and 3 patients (2.9\%) received surgical + radiation and chemotherapy + radiotherapy (Fig. 7).

Analysis of the indicator of cumulative survival of patients depending on the treatment received (Fig. 8).

According to the calculations $\mathrm{p}=0.0000$, which indicates the effect of treatment method on the cumulative survival rate of patients.

Overall survival (\%) of patients with stage IV rectal cancer depending on method of treatment (Table VIII).
Higher survival rates were seen in patients with stage IV rectal cancer, who received surgery + chemotherapy and chemotherapy.

The lowest survival rates of patients with surgery were seen in each of the intervals studied. On the 12th month of observation, this indicator was only 5.4\%, compared with $50.4 \%$ in patients, who received chemotherapy and $68.1 \%$ in patients with surgery+ chemotherapy.

$6.8 \%$ patients received chemotherapy, $3.8 \%$ - surgery + chemotherapy. There were no patients with surgery or radiotherapy only at this stage of observation.

According to the results we can say that chemotherapy in the treatment of rectal cancer is effective for patients with stage IV rectal cancer.

\section{DISCUSSION}

Despite the latest diagnostic methods, immunohistochemical studies, microsatellite instability and modern 
treatments based on the molecular profile of the tumour, the results of survival of patients with colorectal cancer remain unsatisfactory, which encourages scientists to continue studying this pathology. Patients with stage II colorectal cancer (RC) are of particular interest, as the choice of adjuvant treatment for these patients depends on negative prognostic factors.

To summarize the results of the study, a correlational relationship between the studied parameters was identified (Table IX).

The marked correlations are significant, at $\mathrm{p}<0.05000$.

There is a correlation between:

- stage and treatment;

- status (died / registered) and treatment;

- status and treatment;

- localization and treatment.

- localization and chemotherapy.

According to the literature, females with stage I-III disease are more prognostically favorable in comparison with males and have better prognosis for survival [15].

According to the study by Dossa F., Acuna S.A., patients who received adjuvant chemotherapy showed better overall survival for 5 years than those who did not receive adjuvant treatment (95.0\% vs. $88.2 \%$ ) [16].

Rectal cancer is currently one of the most common malignant tumors both in Ukraine and in the world.

Despite the latest diagnostic methods, immunohistochemical studies, microsatellite instability and modern treatments, the overall survival of patients remains unsatisfactory.

Even within homogeneous groups of patients, rectal cancer is characterized by a high heterogeneity of the course and response to therapy, which necessitates a more detailed retrospective analysis of case histories and the study of prognostic factors.

\section{CONCLUSIONS}

According to the obtained results, the overall survival of patients correlates with the stage of rectal cancer: we see the highest survival rates in patients with stage II RC and, accordingly, and the lowest - in stage IV RC in each of the studied time intervals.

The use of combined and integrated treatment in patients with stages II and III RC gives a higher rate of cumulative survival of patients at each of the studied intervals.

In step-by-step analysis:

- stage II RC: on the 5th year of observation, the overall survival rate of patients was $8.4 \%, 1.6 \%$ and $7.7 \%$ respectively in patients, who received surgery, radiotherapy or chemotherapy; similar indicators were seen in patients with surgery + radiation therapy, surgery + radiation therapy + chemotherapy and surgery + chemotherapy $45.6 \%, 21.1 \%$, and $30 \%$;

- stage III RC: on the 3rd year of observation the overall survival rate of patients with surgery was $14.1 \%$ against $45.4 \%$ and $32.4 \%$ in patients with a combined treatment (surgery + radiation therapy) and complex treatment (surgery + radiotherapy + chemotherapy) respectively.
For patients with stage IV RC the use of chemotherapy shows a significantly higher rate of cumulative survival of patients. On the 3rd year of observation, $6.8 \%$ of patients received chemotherapy - and 3.8\% - surgery + chemotherapy.

\section{REFERENCES}

1. Jamal A., Cancer C.A., Clin J. et al. Global cancer statistics. 2013;63:11-30.

2. Fedorenko Z.P., Mykhailovych Yu.Y., Gulak L.0. et al. Rak v Ukraini 20172018 [Cancer in Ukraine 2017-2018]. Biul.Nats.Kantser-reiestruUkrainy. 2019; 17:144. (In Ukrainian).

3. Tyuliandin C.A., Moiseyenko V.M. Prakticheskaia Onkolohia: izbrannye lektsii [Practical Oncology: selected lectures]. TOMM tsentr. 2004. (In Ukrainian).

4. Kornek G., Scheithauer W., Anghel R. et al. Konsensus shchodo medykamentoznoho likuvannia raku [Consencus of medication-based treatment of rectal cancer]. Medytsyna svitu. 2008; 1(6):79-90. (In Ukrainian).

5. Tataryn B.B., Kryzhanivska A.E., Holotiuk I.S. et al. Factors of prognosis in rectal cancer patients. Oncology. 2019; 3(81): 245 - 250.

6. Hotko Ye.S. Suchasni aspeky khimioterapii raku tovstoii kyshky [Modern aspects of chemotherapy of rectal cancer]. Zdoroviya Ukraiiny. 2009; 1(5):3-4. (In Ukrainian).

7. Du D., SuZ., Wang D. et al. Optimal interval to surgery after neoadjuvant chemoradiotherapy in rectal cancer: a systematic review and metaanalysis. Clin Colorectal Cancer. 2017; (15):1533-0028(17).

8. Rahbari N., Weitz J., Hohenberger W. et al. Definition and grading of anastomotic leakage following anterior resection of the rectum: a proposal by the International Study Group of Rectal Cancer. Surgery. 2010; 147(3):339-51.

9. Singh K., Gupta M.K., Seam R.K. et al. A prospective randomized trial comparing capecitabine-based chemoradiotherapy with 5-FUbased chemoradiotherapy in neoadjuvant setting in locally advanced carcinoma rectum. Indian J Cancer. 2017; 54(1):347-51. doi: 10.4103/ ij.IIC_174_17.

10. Meyerhardt J.A., Mayer R.J. et al. Systemne likuvanniya kolorektalnoho raku [Systemic treatment of colorectal cancer]. Medytsyna svitu. 2008; 5(1):476-486 (In Ukrainian).

11. Jean G.W., Shah S.R. Epidermal growth factor receptor monoclonal antibodies for the treatment of metastatic colorectal cancer. Phatmacotherapy, 2008; 28(6):742-782.

12. Fernández-Martos C., Nogué M., Cejas P. et al. The role of capecitabine in locally advanced rectal cancer treatment: an update. Drugs. 2012; 72(8):1057-73. doi: 10.2165/11633870-000000000-00000.

13. Peng J., Lin J., Zeng Z. et al. Addition of oxaliplatin to capecitabine-based preoperative chemoradiotherapy for locally advanced rectal cancer: long-term outcome of a phase Il study. Oncol Lett. 2017; 14(4):4543-50. doi:10.3892/0l.2017.6764.

14. Tataryn B.B., Kryzhanivska A.E., Holotiuk V.V. et al. Chemotherapy in colon cancer. Wiad. Lek. 2018; 71 (9): 1674 - 1680.

15. Berger. M.D., Yang D., Sunakawa Yu. et al. Impact of sex, age, and ethnicity/race on the survival of patients with rectal cancer in the United States from 1988 to 2012. Oncotarget. 2016; 7 (33): 53668-53678.

16. Dossa F., Acuna S.A., Rickles A.S. et al. Association Between Adjuvant Chemotherapy and Overall Survival in Patients With Rectal Cancer and Pathological Complete Response After Neoadjuvant Chemotherapy and Resection. 2018; 4 (7): 930-937. 
ORCID and contributionship:

Bohdan Tataryn: 0000-0002-4957-0691 B,D

Anna Kryzhanivska: 0000-0003-4415-4696 ${ }^{E, F}$

Iryna Dyakiv: 0000-0002-3173-7529 A,C

Alina Andriiv: 0000-0002-4905-5497 ${ }^{\mathrm{A}}$

\section{Conflict of interest:}

The Authors declare no conflict of interest.

\section{CORRESPONDING AUTHOR}

Bohdan Tataryn

Ivano-Frankivsk National Medical University

2 Halytska St., 76000 Ivano-Frankivsk, Ukraine

tel: +380501669043

e-mail: boda.tataryn@gmail.com

Received: 20.08 .2020

Accepted: 02.06.2021

A - Work concept and design, B - Data collection and analysis, C - Responsibility for statistical analysis,

D-Writing the article, $\mathbf{E}$-Critical review, $\mathbf{F}$ - Final approval of the article 